\title{
Regulation of $c$-fos expression in primary culture of guinea pig glandular epithelial cells stimulated by growth factors and estradiol
}

\author{
M Jouvenot *, I Pellerin, G Maréchal, M Royez, \\ C Ordener, M Alkhalaf, GL Adessi \\ INSERM U 198, Biochimie Hormonale et des Régulations, \\ 240, route de Dole, 25000 Besançon, France
}

(15th meeting of the INRA development group, Paris, 24-26 May 1989)

Summary - The c-fos expression was investigated in primary culture of guinea pig glandular epithelial cells. These cells were made quiescent by serum deprivation and stimulated with fetal calf serum (FCS, $15 \%)$, 17ß-estradiol $\left(E_{2}, 10^{-8} \mathrm{~mol} / \mathrm{l}\right)$ alone or in combination with epidermal growth factor $(E G F, 100 \mathrm{ng} / \mathrm{ml})$ and insulin $(\mathrm{l}, 10 \mu \mathrm{g} / \mathrm{ml})$. Low levels of $c$-fos mRNA were detectable in quiescent cells and were not increased in cells stimulated with either $E_{2}, E G F, I$, or EGF plus $I$. On the contrary, the c-fos mRNA were early and transiently increased by FCS or $\Xi_{2}$ plus EGF plus I (4.5 and 9.5 fold induction, respectively). This effect was independent of de novo protein synthesis since it was not abolished in the presence of cycloheximide.

It appears that $E_{2}$ acts in a multiple step process including the stimulation by EGF plus insulin.

uterus / epithelial cell / proto-oncogene / growth factor / estradiol

Résumé - Expression de c-fos dans des cellules épithéliales glandulaires d'endomètre en culture primaire : rôle de l'œestradiol et des facteurs de croissance. Nous avons recherché l'expression de c-fos dans des cultures primaires de cellules épithéliales glandulaires d'endomètre rendues quiescentes puis soumises à différents stimuli : sérum de veau foetal (SVF 15\%), 17B-estradiol $\left(E_{2}, 10^{-8}\right.$ mol/l) seul ou en association avec le facteur épidermique de croissance (EGF, $\left.100 \mathrm{ng} / \mathrm{ml}\right)$ et l'insuline $(1,10 \mu \mathrm{g} / \mathrm{ml})$.

Les $A R N$ c-fos étaient à peine détectables dans les cellules quiescentes et non par $E_{2}$, ou EGF, ou l ou EGF + I. Ils étaient augmentés précocément et transitoirement par SVF et par $E_{2}+E G F+1$ (induction 4,5 et 9,5 fois respectivement). Cette réponse était indépendante de la synthèse de novo de protéines puisqu'elle survenait même en présence de cycloheximide.

L'estradiol régule donc l'expression de c-fos quand il est inclus dans un processus multi-étapes faisant intervenir la stimulation par des facteurs de croissance.

utérus / cellules épithéliale / proto-oncogène / facteur de croissance / estradiol

* Correspondence and reprints 


\section{INTRODUCTION}

Proto-oncogenes are normal cellular genes whose alteration has been implicated in cancerous proliferation and transformation (Bishop, 1987). Recent evidence supports the hypothesis that these genes play key roles in the biochemical pathways controlling normal cell proliferation. One class of proto-oncogenes, including $c$-myc and $c$-fos, encodes nuclear proteins whose precise function is unknown. Numerous reports have established that the expression of these genes may be regulated by protein hormones and growth factors (Adamson, 1987). In vivo studies for hormone responsive cells have associated c-fos and c-myc expression with the response to growth factor or estrogen stimulation (Loose-Mitchell et al, 1988; Weisz and Bresciani, 1988). In the present study, we investigated the expression of $c$-fos gene in primary culture of uterine epithelial cells (from guinea pig) stimulated to grow.

\section{MATERIAL AND METHODS}

\section{Cells and culture conditions}

Epithelial cells were isolated and cultured as previously described (Chaminadas et al, 1986). In brief, after the appropriate growth time, the subconfluent cultures were made quiescent by serum deprivation for $60 \mathrm{~h}$. Then, the $G_{0} / G_{1}$ synchronized cells were stimulated either with fresh fetal calf serum (FCS 15\%) or with $1 \%$ DCC-FCS (dextran charcoal-treated fetal calf serum) plus epidermal growth factor (EGF, 100 $\mathrm{ng} / \mathrm{ml}$ ) and/or insulin $(\mathrm{l}, 10 \mu \mathrm{g} / \mathrm{ml})$ and/or estradiol $\left(E_{2}, 10^{-8} \mathrm{~mol} / \mathrm{l}\right)$, with or without cycloheximide (chx, $10 \mu \mathrm{g} / \mathrm{ml}$ ). The control cells were either submitted to $1 \%$ FCS (vs FCS $15 \%$ stimulated cells) or to $1 \%$ DCC-FCS (vs cells stimulated by $1 \%$ DCC-FCS plus a combination of $E_{2}$ and growth factors).

\section{Preparation of RNA}

Total RNA was isolated from stimulated and unstimulated control cells at different times, using the AGPC method (Chomczynski and Sacchi, 1987). Samples of total RNA (15 $\mu \mathrm{g})$ from control and treated cells were denatured and slotted onto nylon filters. After baking $\left(80^{\circ} \mathrm{C}, 2 \mathrm{~h}\right)$, the filters were probed with $v$-fos obtained from Oncor (Gaithersburg, MD, USA) and labelled with ${ }^{32} \mathrm{P}-\mathrm{dCTP}$ by nick translation.

\section{Hybridization analysis}

The filters were prehybridized and hybridized at $42{ }^{\circ} \mathrm{C}$ in the presence of $50 \%(\mathrm{v} / \mathrm{v})$ formamide. After stringent washes, the filters were exposed to $X$-ray films. Autoradiographies were quantified by scanning densitometry.

\section{RESULTS}

\section{Effect of fetal calf serum on c-fos mRNA concentration}

Quiescent synchronized epithelial cells were stimulated unspecifically by $15 \%$ FCS. To monitor c-fos mRNA levels, slot blot analysis was performed on RNAs isolated at various times after serum addition. The results obtained with $v$-fos DNA probe are shown in figure $1 A$ as specific hybridization signals. Low levels of c-fos RNA were detectable in quiescent cells. A 4.5fold increase in $c$-fos mRNA levels was achieved by the addition of $15 \%$ FCS. The c-fos mRNA levels increased within 30 min, and the expression returned to the basal level within $90 \mathrm{~min}$. Such an induction could not be obtained with $1 \%$ FCS (control cells).

\section{Effect of estradiol on c-fos mRNA concentration}

We investigated the possibility that the increase of c-fos mRNA represents an 

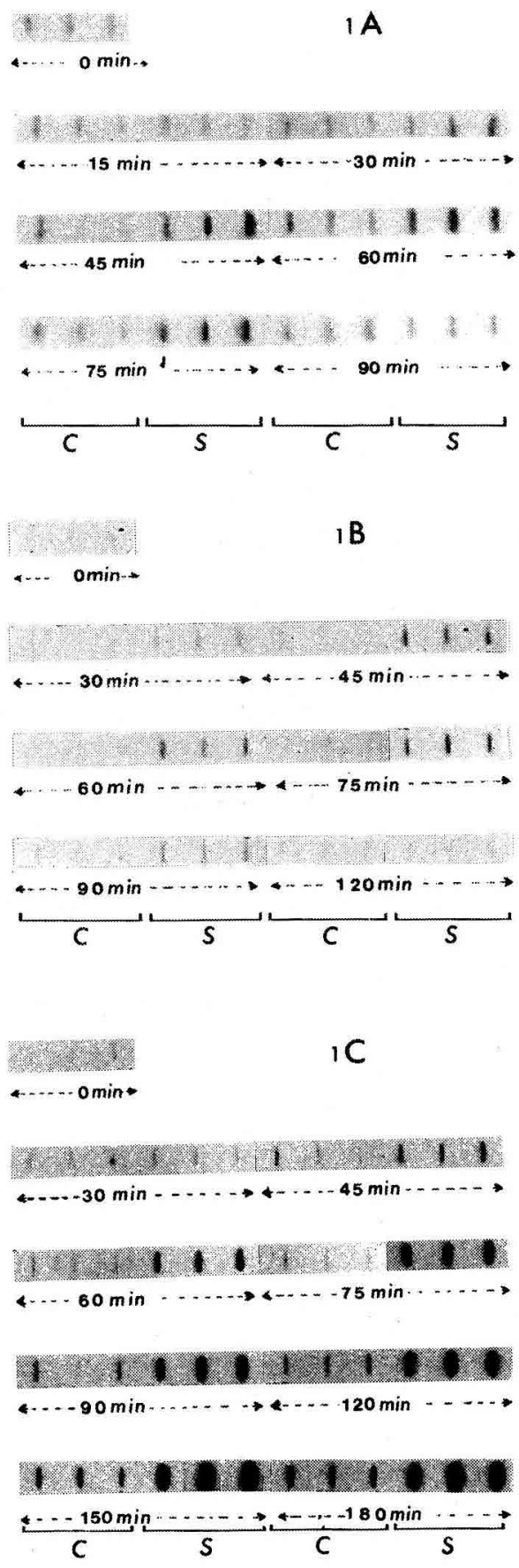

early response to the hormone stimulation, as well as to unspecific serum stimulation. Quiescent cells were treated with either $10^{-8} \mathrm{~mol} / /, \mathrm{E}_{2} 1 \%$ DCC-FCS, $4 \mathrm{mmol} / \mathrm{l} \mathrm{L}$ glutamine and $20 \mathrm{mmol} / \mathrm{l}$ Hepes buffer $E_{2}$ or with $1 \%$ DCC-FCS, $4 \mathrm{mmol} / \mathrm{l} \mathrm{L}$ glutamine and $20 \mathrm{mmol} / \mathrm{l}$ Hepes buffer (control cells). The levels of c-fos mRNA were assessed immediately (time 0 ) and at different times after treatment.

Throughout $3 \mathrm{~h}, \mathrm{E}_{2}$ did not affect the c-fos mRNA level, compared to the level in the control cells (data not shown).

\section{Effect of growth factors on c-fos mRNA concentration}

No transient induction of c-fos gene was observed when EGF or I (in basal medium: $1 \%$ DCC-FCS, $4 \mathrm{mmol} / \mathrm{l}$ L-glutamine and $20 \mathrm{mmol} / \mathrm{l}$ Hepes buffer) was added to quiescent epithelial cells. Treatment by both growth factors did not have any further effect. In these 3 cases, the $c$-fos expression at different times (0-180 min) was the same as that observed for control cells in the presence of basal medium alone (data shown).

Fig 1. Giene expression during transition of epithelial cultured cells from quiescence. Hybridization signals between $32 \mathrm{P}$ - $v$-fos DNA and total RNA (15 $\mu \mathrm{g})$ extracted at indicated times following addition of: 1A) $1 \%$ FCS in basal medium plus insulin ( $1 \mu \mathrm{g} / \mathrm{ml}$ ) for $\mathrm{C}$ (control cells); $15 \%$ FCS in basal medium plus insulin $(1 \mu \mathrm{g} / \mathrm{ml})$ for $S$ (stimulated cells); 1B) $1 \%$ DCC-FCS in basal medium for $\mathrm{C}$ (control cells); $1 \%$ DCC-FCS in basal medium plus $E_{2}$ plus EGF plus I for $S$ (stimulated cells); 1C) $1 \%$ DCC-FCS in basal medium plus $\mathrm{Chx}(10 \mu \mathrm{g} / \mathrm{ml})$ for $\mathrm{C}$ (control cells); $1 \%$ DCC-FCS in basal medium plus $\mathrm{Ch} \times(10 \mu \mathrm{g} /$ mi) plus $E_{2}$ plus EGF plus I for $S$ (stimulated cells). Basal medium consisted of: phenol-red free RPMl 1640, $4 \mathrm{mmol} / \mathrm{l}$ L-glutamine and 20 $\mathrm{mmol} / \mathrm{I}$ Hepes buffer. 


\section{Effect of growth factors and estradiol}

The results are shown in figure 1B. The level of $c$-fos was significantly increased by EGF plus I plus $E_{2}$. The mRNA concentration peaked at $75 \mathrm{~min}$ and returned to the basal level within $1 \mathrm{~h}$. Compared to the control, a 9.5-fold increase in c-fos mRNA levels was achieved by addition of growth factors plus $E_{2}$. As shown in figure $1 C$, when the stimulation (EGF plus I plus $E_{2}$ ) was performed in the presence of chx, the c-fos mRNA level was further increased and did not return to the basal level during the experimental period. The ratio to the control reached a maximum value of 23.8 at $120 \mathrm{~min}$ and decreased in the following hour. This fall in the ratio was due to the slight increase of the mRNA level in the control.

\section{DISCUSSION}

The type of RNA analysis used here measures steady-state level. Therefore, we are unable to distinguish whether the increase in the level of $c$-fos mRNA and its rapid disappearance are the results of a modulated rate of transcription only, or whether it also reflects modulation of $c$-fos mRNA stability. However, our results demonstrate that:

- fos mRNA level is increased in quiescent epithelial cells stimulated by FCS or growth factors plus $E_{2}$;
- this increase appears to be independent of de novo protein synthesis since it is not prevented by chx treatment;

- it cannot be observed in the presence of $\mathrm{E}_{2}$ alone or EGF plus I.

Other results obtained in our laboratory suggest that the expression of fos gene in uterine epithelial cultured cells is not correlated to DNA synthesis, but correlated to cell proliferation.

\section{REFERENCES}

Adamson ED (1987) Oncogenes in development. Development 99, 449-471

Bishop MJ (1987) The molecular genetics of cancer. Science 235, 305-311

Chaminadas G, Propper AY, Royez M, Prost O, Adessi GL (1986) Culture of epithelial and stromal cells of guinea-pig endometrium and the effect of cestradiol-17 $\beta$ on the epithelial cell. J Reprod Fertil 77, 547-558

Chomczynski P, Sacchi N (1987) Single-step method of RNA isolation by acid guanidinium thiocyanate-phenol-chloroform extraction. Anal Biochem 162, 156-159

Loose-Mitchell DS, Chiappetta C, Stancel GM (1988) Estrogen regulation of $c$-fos messenger ribonucleic acid. Mol Endocrinol 2, 946951

Weisz A, Bresciani F (1988) Estrogen induces expression of $c$-fos and $c$-myc protooncogenes in rat uterus. Mol Endocrinol 2, 816824 